\title{
紫外レーザー照射に対する石英材料内部損傷しきい値の温度依存性
}

三上 勝大 ${ }^{1}$, 本越 伸二 ${ }^{2}$, 藤田 雅之 $^{1,2}$, 實野 孝久 ${ }^{1}$, 高井 正憲 ${ }^{3}$, 宰原 健二 ${ }^{4}$, 堀越 秀春 ${ }^{4}$

大阪大学レーザーエネルギー学研究センター（テ565-0871 大阪府吹田市山田丘2-6）

2 (財) レーザー技術総合研究所 ( $5550-0004$ 大阪市西区勒本町1-8-4)

3東ソー (株)（下105-8623 東京都港区芝3丁目8番2号）

4東ソー・エスジーエム (株)（†746-0006 山口県周南市開成町4555)

\section{Temperature Dependence of Damage Thresholds in Silica Glasses with UV Laser}

\author{
Katsuhiro MIKAMI, ${ }^{1}$ Shinji MOTOKOSHI, ${ }^{2}$ Masayuki FUJITA, ${ }^{1,2}$ \\ Takahisa JITSUNO, ${ }^{1}$ Masanori TAKAI, ${ }^{3}$ Kenji SAIHARA, ${ }^{4}$ and Hideharu HORIKOSHI ${ }^{4}$ \\ ${ }^{1}$ Institute of Laser Engineering, Osaka University, 2-6 Yamada-oka, Suita, Osaka 565-0871 \\ ${ }^{2}$ Institute for Laser Technology, 1-8-4 Utsubo-honmachi, Nishi-ku, Osaka 550-0004 \\ ${ }^{3}$ Tosoh Corporation, 3-8-2 Shiba, Minato-ku, Tokyo 105-8623 \\ ${ }^{4}$ Tosho SGM Corpotation, 4555 Kaiseicho, Syunanshi, Yamaguchi 746-0006
}

(Received April 16, 2010)

\begin{abstract}
Laser-induced damage thresholds (LIDTs) in silica glasses at temperature from $123 \mathrm{~K}$ to $473 \mathrm{~K}$ were measured with a $355-\mathrm{nm}$ wavelength at a 4-ns pulse duration. As the result, LIDT increased with decreasing temperature and the change rates $(\Delta \mathrm{D} . \mathrm{T}$.) of the LIDT on temperature were almost constant for five samples with different concentrations of impurities.
\end{abstract}

Key Words: Laser-induced damage, Silica glass, Temperature dependence, Contamination

1. はじめに

高出力レーザーシステムにおける光学素子のレーザー 損傷しきい值は，レーザーの出力を制限する極めて重要 なパラメータの1つである。レーザー媒質としての Yb:YAGは，100 K以下に冷却することにより4準位とし て動作し，熱伝導率などの物性が向上する点が着目され ている。近年，このレーザー媒質を用いた次世代高出力 レーザーシステムの開発が進められている11. しかし冷 却Yb:YAGレーザーのように，光学素子の温度を変化さ せた場合のレーザー損傷しきい值に対する研究は数少な い. A. A. Manekovは $\mathrm{NaCl}$ 結晶の内部レーザー損傷しき い值を77 Kから $800 \mathrm{~K} の$ 温度範囲でNd:YAGレーザー基本 波，第二高調波，第三高調波，ルビーレーザーそして $\mathrm{CO}_{2}$ レーザーを用いて評価を行った ${ }^{2)}$ Ｌ． D. Merkleらは 石英ガラスと BK7 光学ガラスの内部レーザー損傷しきい 值を，室温と液体窒素温度においてマルチモード $\mathrm{Nd}: \mathrm{YAG}$ レー゙ー基本波㧍よび第二高調波を用いて評価 した ${ }^{3)}$. H. R. Plantenakらは, 半導体材料である結晶シリ コンのレーザー損傷しきい值の温度依存性を Nd:YAG レーザー基本波を用いて $298 \mathrm{~K}$ から $773 \mathrm{~K}$ の温度範囲で評 価している4)。いずれの研究においても，常温における レーザー損傷しきい值より低温では増加し，高温では減 少する傾向が報告されているが, 完全な機構の解明には
至っていない

本研究では, 試料温度がレーザー損傷機構に与える影 響を解明することを目的とする。我々はこれまでに $123 \mathrm{~K}$ から $473 \mathrm{~K}$ の温度範囲で，石英バルク材料の内部 レーザー損傷しきい值をNd:YAGレーザー基本波(波長 $1064 \mathrm{~nm}$ ，パルス幅4 ns）により評価を行った ${ }^{5)}$ ）その結 果，冷却するに従ってレーザー損傷しきい值は直線的に 増加した。また，含有不純物濃度が高いものほどレー ザー損傷しきい值は減少するが，顕著な温度依存性を示 し，低温では高純度材料と同等のレーザー損傷しきい值 を得た。本研究では，これまで評価のなされていなかっ た紫外レーザー（波長 $355 \mathrm{~nm}$ ，パルス幅 $4 \mathrm{~ns}$ )による石英 バルク材料の内部レーザー損傷しきい值温度依存性を $123 \mathrm{~K}$ から $473 \mathrm{~K}$ の温度範囲で評価した。

\section{2. 実験方法}

実験配置図をFig. 1に示す。入射する $Q$ スイッチ

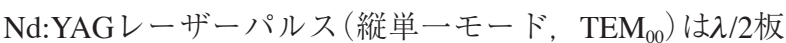
とポラライザーを使用してエネルギーの調整を行った。 入射レーザーエネルギーのモニターは，ビームスプリッ ターを用いて入射レーザー光の一部を取り出し，予め校 正されたバイプラナー光電管を用いてレーザーパルスの ピーク電圧值を計測することで行った。第三高調波は2 


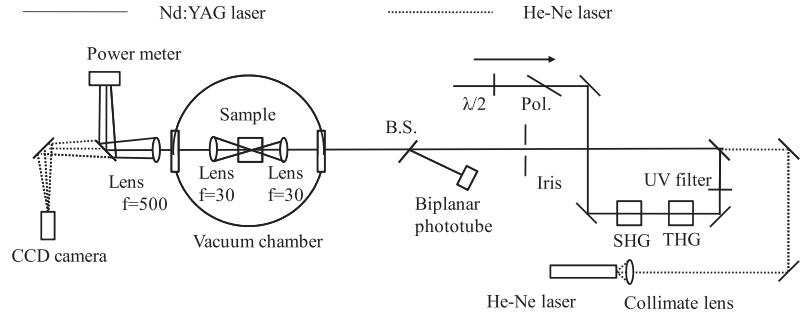

Fig. 1 Experimental layout of LIDT measurement.

つのKDP波長変換結晶を用いて発生させた。測定サンプ ルおよび集光レンズ $(f=30 \mathrm{~mm})$ は, 冷却時の結露を防 ぐために真空チャンバー(真空到達度〜 50 mTorr) 内に設 置した，集光点のレーザースポットサイズはガウス分布 $1 / e^{2}$ で定義し, 空気中で測定すると直径 $30 \mu \mathrm{m}$ であっ た. 測定サンプルは銅製のサンプルホルダーに取り付け た.サンプル表面とサンプルホルダー間に白金測温抵抗 体を取り付け温度計測し, 液体窒素とシーズヒーターを 用いてサンプルホルダーを測定温度で保持することで温 度調整を行った。保持する時間は一定とし, 熱伝導の式 より試料中心部の温度は, 測定温度の $\pm 5 \mathrm{~K}$ 以内である と見積られた。

本実験でのレーザー損傷しきい值は“N-on-1”テストを 用いて決定した。この方式は，照射位置を変えずに入射 エネルギーを徐々に上げレーザーを照射するものであ る. 照射毎にレーザー損傷の有無を確認し, レーザー損 傷が生じたレーザーエネルギー密度をレーザー損傷しき い值として採用した。 レーザー損傷の検出には, (1)プ ラズマ発光，（2）透過Nd:YAGレーザーエネルギー変化,

(3) 同軸に通したHe-Neレーザー透過パターン変化の3種 類を併用した (Fig. 2)

測定サンプルには, 市販の異なる含有不純物濃度を持 つ5種類の石英バルク材料(東ソー・クオーツ(株)製)を 用意した ${ }^{6)}$. これらの $\mathrm{OH}$ 基および金属不純物の含有濃 度 (公称值) をTable 1に示す. ED-A, ED-BおよびESグ レードは合成石英である，ED-A，ED-Bグレードは高純

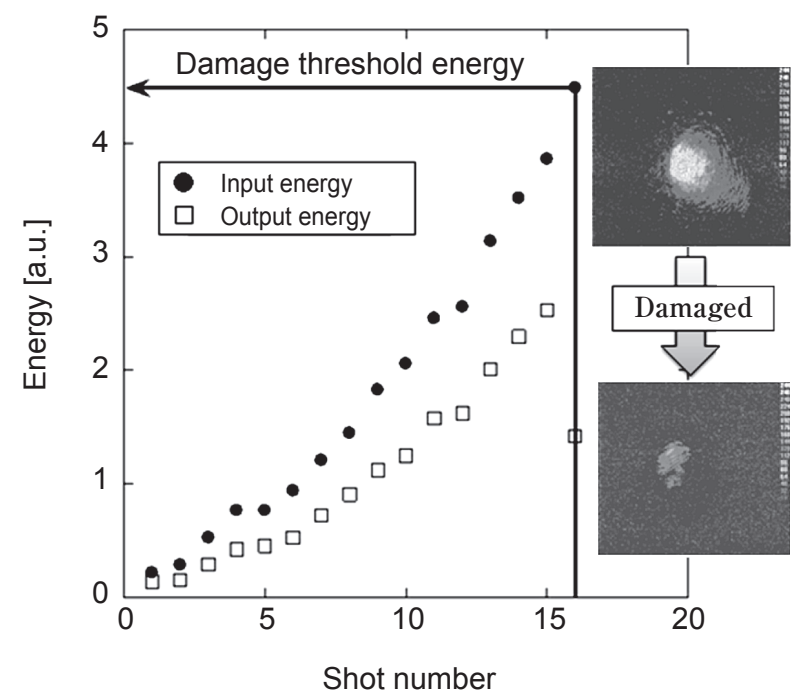

Fig. 2 Example of N-on-1 measurement and damage detections.
Table 1 Concentration of impure materials in silica glass samples. $^{7)}$

\begin{tabular}{ccccccccccc}
\hline & Grade & $\mathrm{Al}$ & $\mathrm{Ca}$ & $\mathrm{Cu}$ & $\mathrm{Fe}$ & $\mathrm{Na}$ & $\mathrm{K}$ & $\mathrm{Li}$ & $\mathrm{Mg}$ & $\mathrm{OH}$ \\
\hline \hline \multirow{3}{*}{$\begin{array}{c}\text { Synthetic } \\
\text { silica }\end{array}$} & $\mathrm{ED}-\mathrm{A}$ & $<0.01$ & $<0.01$ & $<0.01$ & $<0.01$ & $<0.01$ & $<0.01$ & $<0.01<0.01$ & $<200$ \\
\cline { 2 - 10 } & $\mathrm{ED}-\mathrm{B}$ & $<0.01$ & $<0.01$ & $<0.01$ & $<0.01$ & $<0.01$ & $<0.01$ & $<0.01$ & $<0.01$ & $<10$ \\
\cline { 2 - 10 } & $\mathrm{ES}$ & 0.1 & 0.1 & 0.01 & 0.05 & 0.05 & 0.05 & 0.05 & $<0.01$ & 1000 \\
\hline \multirow{2}{*}{$\begin{array}{c}\text { Fused } \\
\text { silica }\end{array}$} & $\mathrm{S}$ & 0.7 & $<0.01<0.01$ & 0.05 & 0.3 & $<0.01<0.01<0.01$ & 160 \\
\cline { 2 - 9 } & $\mathrm{N}$ & 8 & 0.6 & $<0.01$ & 0.2 & 0.6 & 0.1 & $<0.01$ & 0.04 & 200 \\
\hline
\end{tabular}

度であり双方の違いはOH基のみである，ESグレードは 紫外域の透過率を向上させるために大量の $\mathrm{OH}$ 基を有し ている，SおよびNグレードは溶融石英であり，Sグレー ドは合成材を溶融したものであり， Nグレードは天然水 晶を溶融したものであるため, 最も純度の悪い材料であ る。各サンプルのサイズは $30 \times 30 \times 30 \mathrm{~mm}^{3}$ であり，対 向2面に光学研磨を施した。（平面度 $\lambda$, 表面粗さ $<3 \mathrm{~nm}$ )

\section{3. 評価結果および考察}

評価結果をFig. 3に示す. 各プロットはN-on-1テスト を3回行った平均值であり，最大值と最小值をエラー バーで表した。含有不純物濃度の高いサンプルほど，常 温におけるレーザー損傷しきい值は低下した。また，冷 却するに従って，レーザー損傷しきい值は増加した。こ の傾向は1064 nm光に対する石英材料内部損傷しきい值 の場合と同じである ${ }^{5)}$. また, Fig. 3における各直線の傾 きを $\Delta$ D.T.とする。この值が大きいほど，Fig. 3の直線の 傾きが大きく温度依存性が強いことを示す．Fig. 4は横 軸に (a)アルミニウム, (b) ナトリウム, (c) 鉄, (d) 水酸 基の含有不純物濃度, 縦軸に $\Delta$ D.T.をとった. Sグレード を除く全てのサンプルで直線の傾きはほぼ同じであっ Temperature $\left[{ }^{\circ} \mathrm{C}\right]$

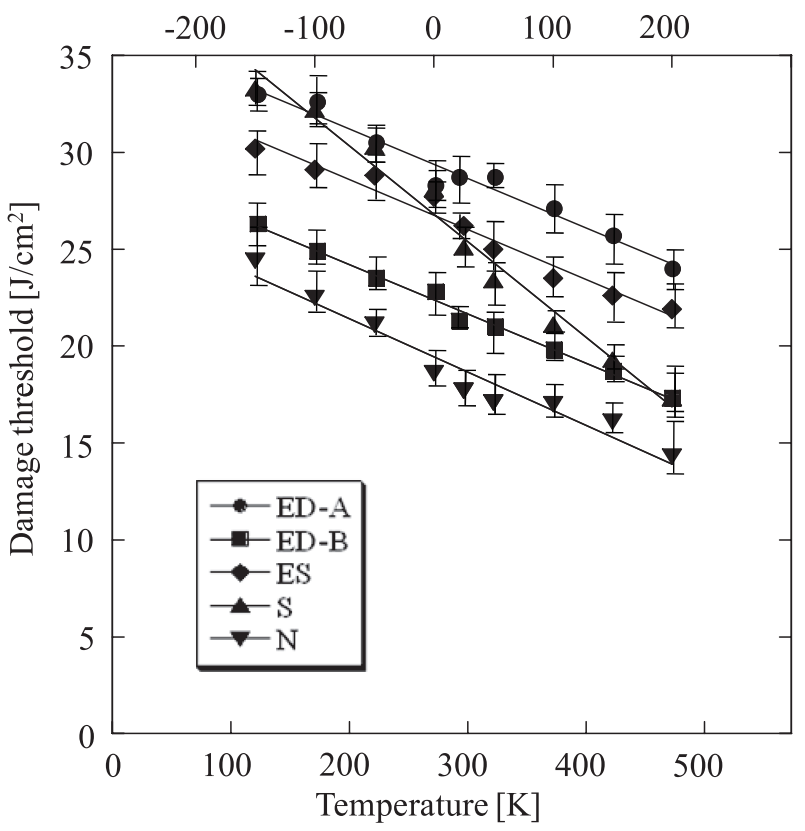

Fig. 3 Dependences of laser-induced damage thresholds on temperature in silica glasses. OED-A grade, $\square$ ED-B grade, $\Delta$ ES grade, $\Delta \mathrm{S}$ grade and, $\boldsymbol{\nabla N}$ grade. 

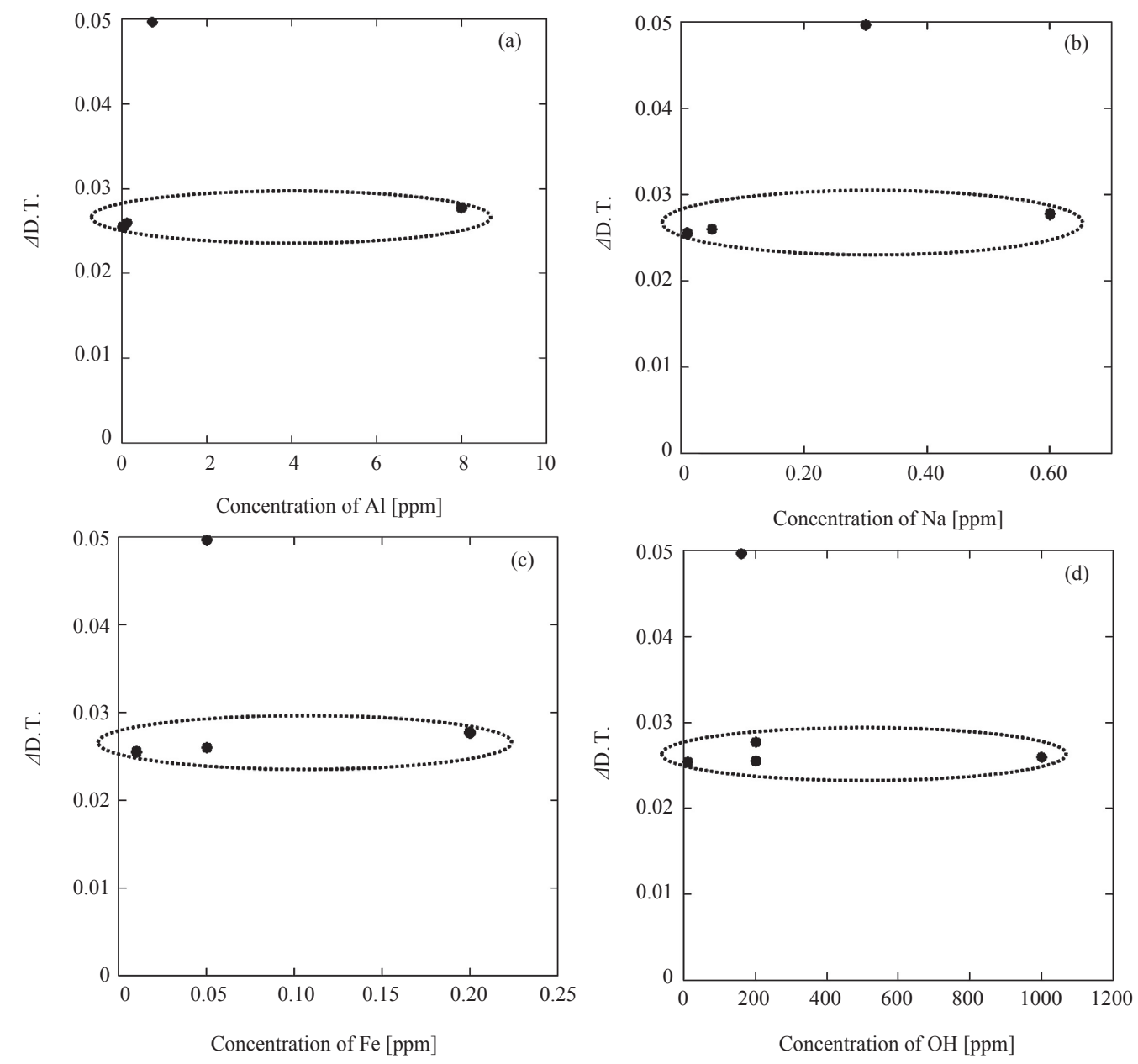

Fig. 4 Relationships between temperature dependence of LIDT and impurities. (a), (b), (c), and (d) are aluminum, sodium, iron, and hydroxyl, respectively.

た、 Sグレードのみ違う $\Delta$ D.T.を示した原因は分かってい ない. $\Delta$ D.T.が不純物濃度に依らない結果は1064 nm光の 場合と異なり，支配的な損傷機構が異なることを示唆し ている.

レーザー損傷機構は，レーザーが入射することにより 誘電体中に自由電子が生成する過程と, その自由電子が レーザーの光電場で加速され電子雪崩(雪崩イオン化) と なる過程に分けられる。自由電子の生成する過程は, 本 研究では波長355 nmの紫外光を用いていることから, 多光子吸収が重要である. P. Braunlichらは $\mathrm{NaCl}$ 結晶の内 部レーザー損傷しきい值をルビーレーザー基本波および 第二高調波を用いて測定し，その結果を用いて短パル ス・短波長になるほど多光子吸収過程が初期の自由電子 生成で重要であることを理論的に説明している7). 多光 子吸収における自由電子生成量は基底準位の数密度と遷 移確率の積で示される7)。量子光学において，単位時間 当たりの遷移確率 $w_{12}$ は (1) 式で示される ${ }^{8)}$.

$$
w_{12}=\frac{\pi\left|\mu_{21}\right|^{2} U_{\left(\omega_{0}\right)}}{3 \varepsilon_{0} \hbar^{2}}
$$

ここで $\mu$ は電気双極子モーメント，Uは共鳴角周波数 $\omega_{0}$ の電磁波エネルギー密度, $\varepsilon_{0}$ は真空の誘電率である. 従って, 遷移確率は入射電磁波の共鳴角周波数成分 $\left(\omega_{0}\right)$
のエネルギー密度と電気双極子モーメントの2乗に比例 する。また，電気双極子モーメントは電荷量と空間座標 で定義されることから，遷移確率は温度に独立である．

一方, 各準位の電子数密度はボルツマン分布により温度 の関数であるが, 石英材料は約 $9 \mathrm{eV}$ の幅広いバンド ギャップを持つことから, $350{ }^{\circ} \mathrm{C}$ 程度の変化で価電子帯 から伝導帯への熱励起はほとんど生じない，数密度の変 化は，含有不純物が半導体におけるドナーゃアクセプタ のように振る舞い, 電子の数密度を変化させると考えら れる。そのため含有不純物濃度の高い材料ほど温度変化 に対して敏感に自由電子生成量が変化するものと考えら れる。事実，1064 nm光に対する石英材料の損傷しきい 值温度依存性では含有不純物が多いものほど急激な AD.T.の変化を示している5)。このことを踏まえて考える と， $355 \mathrm{~nm}$ 光では含有不純物濃度に依らず， $\Delta$ D.T.が一 定であるという結果が得られたことから，材料温度が レーザーによる自由電子生成過程へ及ぼす影響は小さ く, 電子雪崩の成長過程への影響が大きいと考えること ができる.

M. Sperksらは，理論的に $\mathrm{NaCl}$ 結晶中のレーザーによ る電気絶縁破壊を説明している⿱日十)。その中で, (2)式の 電子の輸送方程式と，（3)式の電子の増加が指数関数的 であるという仮定が用いられている. 


$$
\begin{gathered}
\frac{\partial n_{(x, t)}}{\partial t}+\frac{\partial J}{\partial x}=0 \\
n_{(x, t)}=n_{(x)} \exp (\beta t)
\end{gathered}
$$

ここで $n_{(x, t)}$ は空間 $x$, 時間 $t$ における電子密度, $J$ は電流密 度, $\beta$ は電子雪崩による電子増倍係数である。(2)式と (3)式より (4)式が示される.

$$
\frac{d J_{(x)}}{d x}=\beta n_{(x)}
$$

この式より, 微小空間の電流密度の変化は, 電子密度と 電子雪崩による電子増倍係数の積であることが表わされ る。また，(4)式の妥当性はHolsteinらによってボルッマ ン方程式より検討されている ${ }^{10)}$. ここで示されている電 流密度は(5)式で一般に示される。

$$
J=n_{(x)} u \boldsymbol{E}+D \frac{d n_{(x)}}{d x}
$$

(5) 式の右辺第一項は移動度 $u$ と電場 $\boldsymbol{E}$ で決定されるドリ フト電流であり, 第二項は拡散係数 $D$ と電子密度勾配で 決定される拡散電流である。（4)式と(5)式より，(6)式 が得られる。

$$
n_{(x)} u \boldsymbol{E}+D \frac{d n_{(x)}}{d x}=\int \beta n_{(x)} d x
$$

この式は, 任意の空間で電子雪崩によって増倍される電 子の総数は, ドリフト電流や拡散電流が増えることによ り増加することを意味する. Sparksらの報告でも電子の 拡散が議論されている に示されるアインシュタインの関係式より, 拡散係数は 温度に比例して増加することが知られている ${ }^{11)}$

$$
D=\frac{u k T}{e}
$$

従って, 温度が増加することによって線形に拡散電流が 増加し, 電子雪崩が生じやすくなり, レーザー損傷しき
い值が減少したと定性的に理解することができる，拡散 係数 $D$ 以外の因子の関係は明らかでない. 自由電子密度 $n_{(x)}$, 移動度 $u$, 電子増倍係数 $\beta$ に対する, 不純物濃度や 温度が与える影響について実験的，また理論的研究を行 うことにより，レーザー損傷機構の理解を深めることが 必要である。

$$
\text { 4. まとめ }
$$

本研究では含有不純物濃度が異なる5種類の石英バル ク材料に対して, $-150{ }^{\circ} \mathrm{C} \sim 200{ }^{\circ} \mathrm{C}(123 \mathrm{~K} \sim 473 \mathrm{~K})$ まで の温度範囲における内部レーザー損傷しきい值温度依存 性をNd:YAGレーザー第三高調波を用いて評価した。そ の結果, 低温になるに従いレーザー損傷しきい值は上昇 し，ほとんどのサンプルでその変化はサンプルの含有不 純物濃度に依らないことを明らかにした。低温になるに 従いレーザー損傷しきい值が増加する温度依存性は, 電 子雪崩過程の温度依存性に起因する可能性がある。これ は, レーザー損傷機構を解明していく上で重要な結果で ある。

\section{参考文献}

1）河仲準二, 吉田陽, 安原亮, 川嶋利幸, 菅博文：レー ザー研究 36 (2008) 549.

2) A. A. Manenkov: Natl. Bur. Stand. (U. S.) Spee. Publ. 541 (1978) 455.

3) L. D. Merkle and D. Kitriotis: Phys. Rev. B 38 (1988) 1473.

4) J. R. Platenak, R. M. Walser, and M. F. Becker: Damage in Laser materials:1986, NIST (U. S.) Spec. Publ. 752 (1987) 216.

5) K. Mikami, S. Motokoshi, M. Fujita, T. Jitsuno, J. Kawanaka, and R. Yasuhara: Proc. SPIE 41th ANNUAL LASER DAMAGE SYMPOSIUM, Colorado, 2009, 7504 (2010) 75041R-1-5.

6) Production Catalog (Tosoh corporation, Ltd., Tokyo, Japan 2008).

7) P. Braunlich and A. Schmid: Appl. Phys. Lett. 26 (1975) 150.

8）櫛田 孝司：量子光学 (朝倉書店, 1981) p. 68.

9) M. Sparks, D. L. Mills, R. Warren, T. Holstein, A. A. Maradudin, L. J. Sham, E. Loh, Jr., and D. K. King: Phys. Rev. B 24 (1981) 3519.

10) L. H. Holway Jr. and D. W. Frandin: J. Appl. Phys. 46 (1975) 279.

11）電気学会：誘電体現象論（オーム社，1973）p. 211. 